МЕХАНІЗМИ РЕАЛІЗАЦІЇ ДЕРЖАВНОЇ ПОЛІТИКИ ПОЛІПШЕННЯ ГАЛУЗІ РОСЛИННИЦТВА ЗАКРИТОГО ҐРУНТУ У СВІТЛІ СУЧАСНИХ ТЕНДЕНЦІЙ ПРОДОВОЛЬЧОЇ БЕЗПЕКИ УКРАЇНИ

\title{
MECHANISMS OF IMPLEMENTATION OF STATE POLICY TO IMPROVE THE INDUSTRY OF INDOOR CROP PRODUCTION IN THE LIGHT OF CURRENT TRENDS IN FOOD SECURITY OF UKRAINE
}

УДК 338.43:351.86(477)

DOI https://doi.org/10.32843/

pma2663-5240-2021.23.9

Міненко С.В.

к. техн. наук,

доцент кафедри машиновикористання та сервісу технологічних систем

Поліський національний університет

Савченко В.М.

к. техн. наук, доцент,

завідувач кафредри

машиновикористання та сервісу

технологічних систем

Поліський національний університет

Савченко Л.Г.

к. іст. наук,

доцент кафедри електрифікації,

автоматизації виробництва та

інженерної екології

Поліський національний університет
Нині в Україні гостро постала дилема узагальнення передового досвіду вирощування сільськогосподарських культур у закритому ґрунті, важливим завданням є також визначення основних векторів розвитку державної політики в цьому напрямі. Достеменно відомо, що в умовах стрімкого розвитку науки «публічного управління та адміністрування» й прогресивного державного впливу на розвиток аграрної сфери досить часто в науковому колі використовується поняття «механізм державного управління» та «механізм державного регулювання». Однак, як свідчать численні розвідки, на жаль, не $\epsilon$ системно визначеним безпосередньо сам механізм становлення й поетапної реалізаиії державної політики, зокрема державноі політики в аграрній сорері. Метою статmі $\epsilon$ дослідження особливостей розвитку галузі рослинництва закритого грунту на сучасному етапі, а також визначення основ формування державної політики в аналізованій сорері. Автором запропоновано такі шляхи поліпшення державної політики в аграрному секторі України згідно з реалізацією таких механізмів: на законодавчому рівні (удосконалення нормативно-правої бази); цілеспрямована організаційна діяльність може бути реалізована завдяки чітким адміністративно-організаційним рішенням і директивним указівкам; забезпечення ефрективності функціонування підприємств галузі рослинництва закритого ґрунту $є$ рентабельним лише за обгрунтованої фрінансово-економічної підтримки держави; неоціненну роль, як наголошує автор статmі, відіграє система інформаційного забезпечення мотивації основних учасників ринку галузі рослинництва закритого грунту, в межах якої доцільно розробляти й упроваджувати інструменти вирішення наявних проблем і суперечностей розвитку аграрної сфери в Україні. У результаті грунтовного аналізу теоретичної джерельної бази та практичних свідчень учених автором доведено, що задля ефрективного сталого розвитку ринкової економіки українській державній аграрній політиці варто зосередитися у світлі сучасних тенденцій продовольчої безпеки на створення принципово нового концепту аграрної економіки.

Ключові слова: продовольча безпека, рослинництво закритого ірунту, державна політика, механізми.

Now in Ukraine, sharply faced the dilemma of summarizing the best practices of growing crops in greenhouses, an important task is also to determine the main vectors of state policy in this direction. It is known that under conditions of rapid development of science of "public administration and management" and progressive state influence on development of agrarian sphere the concept of "mechanism of state management" and "mechanism of state regulation" is used quite often in scientific circle. However, as evidenced by numerous reconnaissance, unfortunately, the mechanism of formation and step-by-step implementation of state policy, in particular state policy in the agricultural sphere, is not systematically defined directly. The purpose of the article is to study the peculiarities of the development of indoor crop production at the present stage, as well as to determine the basis for the formation of state policy in this area. The author proposed the following ways of improving public policy in the agricultural sector of Ukraine according to the following mechanisms: at the legislative level (improvement of the regulatory framework) purposeful organizational activities can be implemented due to clear administrative and organizational decisions and directive guidance; ensuring effective functioning of enterprises of crop production industry closed ground is cost-effective only with reasonable financial and economic support of the state and municipal government. As a result of thorough analysis of the theoretical source base and practical evidence of the scientists, the author has proved that for effective sustainable development of the market economy, the Ukrainian state agrarian policy should focus on the creation of a fundamentally new concept of agricultural economy in the light of current trends in food security.

Key words: food security, indoor crop production, state policy, mechanisms.
Постановка проблеми в загальному вигляді. Нині в Україні гостро постала дилема узагальнення передового досвіду вирощування сільськогосподарських культур у закритому ґрунті, важливим завданням $€$ також визначення основних векторів розвитку державної політики в цьому напрямі. Достеменно відомо, що в умовах стрімкого розвитку науки «публічного управління та адміністрування» і прогресивного державного впливу на розвиток аграрної сфери досить часто в науковому колі використовується поняття «механізм державного управління» та «механізм державного регулювання». Однак, як свідчать численні розвідки, нажаль, не є системно визначеним безпосередньо сам механізм становлення й поетапної реалізації державної політики, зокрема державної політики в аграрній сфері.

Аналіз останніх досліджень і публікацій. Вітчизняні та іноземні вчені досліджували різноманітні аспекти виробництва продукції рослинництва закритого ґрунту [8; 9]. 
Модифікаційні вектори розвитку світового ринку овочів закритого ґрунту вивчав І.М. Новак [6]. Детальний системний аналіз собівартості як визначального чинника зміцнення конкурентоспроможності підприємства здійснила Є.В. Прохватілова [12]. Економічним аспектам розвитку плодоовочевого ринку України приділила свою увагу М.Ф. Кисляченко [3]. Екологічні аспекти вирощування овочів і ягід у тепличних умовах дослідили Є.М. Бережняк і Т.В. Гончаренко [1].

Варто зауважити, що результати їхніх досліджень не висвітлюють першооснов формування державної політики розвитку галузі рослинництва закритого ґрунту. На противагу їм, C.І. Урба [13] детально охарактеризувала методологічні засади становлення аграрної галузі в системі забезпечення економічної безпеки держави. Однією з ґрунтовних, на наш погляд, останніх розвідок $€$ дослідження Ю.Ф. Маєвського [5]. У численних працях автор обґрунтував дилему становлення, розвитку та реалізації державної аграрної політики в Україні. Автор запропонував вирішення досліджуваного питання, а саме опис шляхів удосконалення механізмів формування й реалізації державної аграрної політики в нашій державі.

Метою статті є дослідження особливостей розвитку галузі рослинництва закритого ґрунту на сучасному етапі, а також визначення основ формування державної політики в цій сфері.

Виклад основного матеріалу. Забезпеення продовольчої безпеки $€$ постійною проблемою як країн із низьким рівнем економічного розвитку, так і розвинутих країн, які постійно вдосконалюють механізми підтримки продовольчої безпеки [7]. Так, відповідно до Проекту Закону України «Про основні засади державної аграрної політики та державної політики сільського розвитку» від 04.10.2018 № 9162 [11], продовольча безпека держави має бути спрямована на належний рівень продовольчого забезпечення населення, доступ населення без перешкод, фізичний та економічний, до безпечних і якісних продуктів харчування, а також на внесок у глобальну продовольчу безпеку. Забезпечення продовольчої безпеки держави має здійснюватися передусім такими шляхами: «забезпечення вітчизняного виробництва якісного та безпечного продовольства в обсязі, необхідному для гарантування продовольчої безпеки України; також українському виробнику сільськогосподарської продукції варто надавати повсякчас державну підтримку; відповідно сучасним запитам забезпеченням доступу громадян до безпечних харчових продуктів, зокрема у результаті реалізації прикладних наукових досліджень у сфері розробки новіт- ніх харчових продуктів (інгредієнтів) або традиційних харчових продуктів (інгредієнтів), сортів рослин та порід тварин; шляхом участі в міжнародній та регіональній інтеграції, забезпечення доступності продуктів харчування у світі метою якої є стандартизація підходів до реалізації продовольчої безпеки світу загалом; сприяти впровадженню системи моніторингу стану продовольчої безпеки в Україні; дотриманню вимог ЄС щодо безпеки та якості харчових продуктів та ефективної системи ветеринарних та фітосанітарних заходів; продовольчі ресурси, що призначені для забезпечення стратегічних потреб держави, варто постійно оновлювати та сприяти належному зберіганню останніх; варто акцентувати увагу на фундаментальній ролі здійснення моніторингу та прогнозування ринку продукції рослинництва закритого ґрунту; передусім реалізація створеної ефективної системи державного контролю за додержанням законодавства про харчові продукти, побічні продукти тваринного походження та корми із дотриманням здоров'язбережувального вектору державної політики задля сприяння благополуччя біоти, а також захисту життя організмів, спрямованої на запобігання формуванню ризиків, що виникають внаслідок проникнення, укорінення чи поширення організмів які виявляють, шкодочинну дію у відношенні до інших організмів, які є носіями чи проміжними господарями хвороб чи хвороботворних організмів» [11]. Нині одним із основних завдань Міністерства аграрної політики та продовольства України є реалізації загальнодержавна аграрної політики, що спрямована на процвітання агропромислового комплексу та забезпечення продовольчої безпеки держави [11].

В Україні овочівництво являє собою специфічну галузь, яка має певні недоліки, пов'язані 3 низькою транспортабельністю продукції; великим різноманіттям вирощуваних культур (понад 100), для яких є характерним використання специфічної агротехніки; незначною механізацією окремих виробничих процесів, що вимагає значних затрат ручної праці й потребує працівників відповідної спеціалізації щодо обслуговування певних видів техніки, організації товарної обробки, зберігання та реалізації овочів; великою трудомісткістю робіт, що призводить до значних сумарних витрат на виробництво [14, с. 77].

Також відзначимо, що для вирощування сільськогосподарських культур використовуються земельні ділянки сільськогосподарського призначення.

У результаті здійснення виробничо-господарської діяльності конкретну галузь, зокрема 
й тепличну, ми характеризуємо за специфічними індивідуальними особливостями, які під впливом тих чи інших зовнішніх факторів реалізуються та їх основі набувають визначеної організаційно-технологічної структури. Тому, як наголошує В.О. Чайка, використання SWOTаналізу дає нам змогу врахувати дію факторів зовнішнього і внутрішнього середовища (таблиця 1) [14; 15].

Стратегія розвитку галузі рослинництва закритого ґрунту з урахуванням аналізу вищенаведених фактичних даних має бути спрямована на зростання виробництва високоякісної продукції рослинництва, відповідно, 3 мінімізацією витрат на отримання останніх. Що ж потрібно для забезпечення потреби галузі необхідними фінансовими ресурсами? Це передусім створення сприятливих умов для здійснення фінансових операцій, удосконалення інвестиційної, інноваційної, бюджетної та податкової політики. Підтримка держави має бути реалізована впродовж визначених термінів і бути прогнозовано плановою, а не хаотично вибірковою з визначеною сезонною чи політичною активністю керівних ланок органів державної влади. Наприклад, щодо таких нескладних у рамках держави питаннях будівництва нових тепличних комплексів чи постачання енергоносіїв, засобів живлення та захисту рослин. Якщо ж ми говоримо про державну політику в галузі рослинництва закритого ґрунту, на превеликий жаль, досліджувана нами сфера залишається все частіше поза увагою українського законодавця та політикуму загалом.

Відповідно до Закону України «Про державну підтримку сільського господарства України» від 24.06.2004 [10], заходами державної підтримки, що можуть застосовуватися до рослинництва закритого ґрунту, є регулювання цін; фінансова підтримка згідно з вимогами часу; маркетинг і просування продукції на ринок; субсидіювання на рівні державного бюджету має бути в розрахунку на одиницю оброблюваних угідь; доцільним $є$ часткове бюджетне відшкодування вартості висіяного стратегічно репродукційного насіння; виконання цільових бюджетних програм, основою метою яких є підвищення збереження та посилення родючості ґрунтів; виважене й мінімізоване у своєму вираженні ведення сільського господарства на радіаційно забруднених територіях; для власних виробничих потреб техніки, аналоги яких відсутні в нашій державі, варто звільнити від державного мита ввезення в Україну; варто наголосити також на реалізації державної підтримки, пов'язаної із забезпеченням контролю якості й безпеки продуктів харчування [2; 10].
Державна підтримка вирощування рослин у теплицях можлива через фінансування придбання та ремонту теплиць, установлення сучасних систем поливу й використання біологічно безпечних добрив, забезпечення виробництва доступними енергоносіями, створення умов для зберігання, переробки та реалізації зібраних овочів тощо. Такі заходи мають спричинити підвищення ефективності виробництва, якості вирощеної продукції, зниження цін на тепличні овочі, що підвищить попит на них.

На нашу думку, з метою підтримки галузі рослинництва на закритому ґрунті на державному рівні має бути прийнята відповідна стратегія, спрямована на сприяння розвитку галузі шляхом будівництва, модернізації й технічного переоснащення тепличних комбінатів і підприємств; надання державної підтримки в реалізації інвестиційних проектів з будівництва теплиць нового покоління; зниження фінансового навантаження на сільськогосподарських товаровиробників при виробництві продукції рослинництва закритого ґрунту в частині зниження вартості енергоносіїв шляхом субсидування частини витрат на придбання електричної енергії й (або) технологічного газу, на будівництво теплиць нового покоління й придбання устаткування до них. Реалізація заходів такої стратегії сприятиме інноваційному процесу розвитку галузі рослинництва закритого ґрунту, особливо в питаннях підвищення ефективності галузі за рахунок упровадження нових енерго- й ресурсозбережувальних технологій, дасть змогу зробити продукцію сільськогосподарських господарств економічно конкурентоспроможною, підвищити мотивацію для збільшення обсягів виробництва високоякісних овочів і ягід закритого ґрунту, забезпечити в міжсезонний період гарантоване постачання населення України свіжими овочами, регулювати ціновий фактор на споживчому ринку. Реалізація заходів такої програми допоможе забезпечити: 1) економічний ефект: збільшення обсягів виробництва рослинництва закритого ґрунту; збільшення площі зимових теплиць нового покоління; приріст виторгу від реалізації продукції рослинництва закритого ґрунту; 2) бюджетний ефект - обсяг податкових і неподаткових надходжень як у регіональний бюджет, так і в державний; 3) соціальний ефект - збільшення чисельності працівників, зайнятих у галузі рослинництва закритого ґрунту. До основних ризиків, які можуть вплинути на досягнення запланованих результатів, належать: зміна державного й обласного законодавства; недостатній рівень співфінансування з боку інвесторів, а також сільськогосподарських виробників із власних і позикових 


\section{SWOT-аналіз розвитку галузі рослинництва захищеного ґрунту}

\begin{tabular}{|c|c|}
\hline Сильні сторони (S) & Слабкі сторони (W) \\
\hline $\begin{array}{l}\text { - висока якість вітчизняної продукції, відповідність її } \\
\text { екологічним нормам; } \\
\text { - здатність виробляти продукцію в зимовий період; } \\
\text { - великі площі, заняті у виробництві рослинництва } \\
\text { захищеного ґрунту; } \\
\text { - нарощування валового виробництва рослинництва } \\
\text { захищеного ґрунту; } \\
\text { - стабільність реалізації на внутрішньому ринку, } \\
\text { надання переваг українським споживачем } \\
\text { вітчизняній тепличній продукції; } \\
\text { - можливість отримати єдину нині державну } \\
\text { підтримку, що передбачена для галузі рослинництва } \\
\text { захищеного ґрунту: компенсацію відсотків за } \\
\text { позикою в банках }\end{array}$ & $\begin{array}{l}\text { - значне підвищення цін на енергоносії; } \\
\text { - зупинка роботи великої частини тепличних } \\
\text { комплексів у Донецькій і Луганській областях, а також } \\
\text { ктрата територій і продукції з АР Крим; } \\
\text { - відсутність кваліфікованих кадрів для впровадження } \\
\text { нових технологій виробництва овочів закритого ґрунту; } \\
\text { - залежність галузі від імпортного обладнання та } \\
\text { матеріалів; } \\
\text { - складність процесу залучення інвестицій у галузь; } \\
\text { - відсутність гарантій щодо швидкого повернення } \\
\text { інвестованих коштів; } \\
\text { - складність спілкування тепличних виробників і } \\
\text { фінансових інституцій, які не володіють достатньою } \\
\text { мірою технологічними знаннями, не розуміють } \\
\text { механізмів існування відповідного ринку, а також } \\
\text { іх насторожує складний маркетинг у веденні цього } \\
\text { бізнесу; } \\
\text { - обмеження Російською Федерацією експорту } \\
\text { українських овочів захищеного ґрунту; } \\
\text { - складність експорту до країн ЄС вітчизняної тепличної } \\
\text { продукції через її високу собівартість порівняно з } \\
\text { європейською; } \\
\text { - насиченість вітчизняного ринку овочів закритого } \\
\text { ґрунту; } \\
\text { - низька купівельна спроможність населення; } \\
\text { - короткий період зберігання продукції; } \\
\text { - сезонність у виробництві продукції. }\end{array}$ \\
\hline Можливості (0) & Слабкі сторонни (W) \\
\hline $\begin{array}{l}\text { - модернізація та розширення виробничих } \\
\text { потужностей; } \\
\text { - звільнення частки внутрішнього ринку тепличних } \\
\text { овочів від імпортної продукції через подальше } \\
\text { знецінення гривні; } \\
\text { - проникнення вітчизняної тепличної продукції на } \\
\text { зовнішні ринки через можливе знецінення гривні й } \\
\text { запровадження ЗВТ з ЄС; } \\
\text { - упровадження енергоощадних технологій } \\
\text { і використання альтернативних джерел } \\
\text { енергії для оптимізації виробничих витрат, } \\
\text { зниження собівартості, а також для підвищення } \\
\text { конкурентоспроможності вітчизнянї продукції; } \\
\text { - досягнення зменшення трудомісткості в діяльності } \\
\text { тепличних господарств; } \\
\text { - створення науково-практичних центрів на базі } \\
\text { найбільших тепличних господарств країни для } \\
\text { забезпечення галузі висококваліфікованими } \\
\text { кадрами; } \\
\text { - збільшення українськими господарствами } \\
\text { виробництва продукції преміям сегменту й рідкісних } \\
\text { сортів для подальшого заміщення імпортних позицій } \\
\text { на вітчизняному ринку тепличних овочів. }\end{array}$ & $\begin{array}{l}\text { - невизначеність з економічною і політичною ситуацією } \\
\text { в країні; } \\
\text { - подальше здорожчання енергоресурсів; } \\
\text { - продовження Російською Федерацією санкцій на } \\
\text { обмеження експорту вітчизняної тепличної продукції; } \\
\text { - складність або неможливість для багатьох } \\
\text { підприємств галузі пройти процес сертифікації Global } \\
\text { GАР, що водночас закриває для них можливість вийти } \\
\text { на ринки Європи (окрім Прибалтики та Польщі), } \\
\text { Канади, США й інших країн з високим рівнем } \\
\text { купівельної спроможності населення; } \\
\text { - ризики, пов'язані з технологічним процесом: } \\
\text { імовірність захворювання рослин тощо; } \\
\text { - ризики, пов'язані з виникненням стихійних лих. }\end{array}$ \\
\hline
\end{tabular}

Джерело: створено автором на основі аналізу [14; 15].

засобів; несприятлива ринкова кон'юнктура, а також непередбачено високе зростання цін на насіння, добрива, устаткування, матеріали, електричну енергію, які можуть призвести до істотного подорожчання продукції рослинництва й труднощів з її реалізацією. М.А. Латинін уважає, що «механізм державного регулювання аграрного сектора економіки - це спосіб дій суб'єкта регулювання, який ґрунтується на таких функціях і принципах, які забезпечують досягнення поставленої мети та розв'язання протиріч» [4].

Ми переконані, що механізм формування та реалізації державної аграрної політики - це спосіб застосування заходів впливу суб'єкта такої політики щодо коригування (за необхідності) дії ринкового механізму саморегулювання, для подолання «неспроможностей» ринку, забезпечення сталого розвитку аграрної сфери та виконання поставлених цілей і завдань щодо 
продовольчої безпеки, економічної та фізичної доступності продуктів харчування для населення, забезпечення екологічного складника розвитку галузі й сільських територій.

Висновки. У підсумку зауважимо, що потреби ринку та довіра споживача до української продукції дають можливості українським господарствам збільшити виробництво продукції рослинництва на закритому ґрунті. Сучасна державна аграрна політика в Україні має сприяти формуванню принципово нової структури аграрної економіки, орієнтованої на забезпечення продовольчої незалежності держави (виходячи з 5 раціональних норм здорового харчування населення) та поетапну реалізацію завдання підвищення ролі країни на світовому ринку аграрної продукції та продовольства; адаптацію до зовнішньоекономічних та екологічних викликів і кліматичних змін; підвищення якості людського потенціалу й подолання розриву між рівнем життя міського та сільського населення, забезпечення сталого розвитку сільських територій.

\section{ЛІТЕРАТУРА:}

1. Бережняк Є.М., Гончаренко Т.В. Екологічні особливості технологій вирощування овочевих культур в тепличних умовах. Modern problems and ways of their solution in science, transport, production and education. 2013. URL: https://www.sworld.com.ua/ konfer31/427.pdf (дата звернення: 12.05.2021).

2. Земельний кодекс України від 25.10.2001 № 2768-III. URL: https://zakon.rada.gov.ua/laws/ card/2768-14 (дата звернення: 12.05.2021).

3. Кисляченко М.Ф., Семененко Н.М. Світовий ринок продукції закритого овочівництва. Продуктивність агропромислового виробництва. 2018. № 7. C. 73-78.

4. Латинін М.А. Теоретичні підходи щодо визначення механізму державного регулювання розвитку аграрного сектора економіки України. Державне управління: теорія та практика. 2005. № 2. URL: http://www.academy.gov.ua/ej2/index.html (дата звернення: 12.05.2021).

5. Маєвський Ю.Ф. Механізми державного управління інституціонального середовища в аграрному секторі економіки України. Вісник Національного університету цивільного захисту України. Харків : Вид-во НУЦЗУ, 2020. Вип. 2 (13). С. 182-189.

6. Новак І.М. Стан та проблеми трансорормації доходів населення в інвестування аграрної галузі. Соціально-економічні проблеми сучасного періоду України. 2015. Вип. 5. С. 98-101.

7. Основні завдання Мінекономіки у ссрері сільського господарства. Офріційний інтернет-портал Міністерства аграрної політики та продовольства України. URL: https://agro.me.gov.ua/ua/pro-nas/ misiya-ta-strategiya (дата звернення: 12.05.2021).

8. Правове регулювання виробництва сільськогосподарської продукції : навчальний посібник / за ред. доктора юридичних наук, професора А.М. Статівки. Харків : Юрайт, 2015. 272 с.

9. Приліпка О.В., Цизь М. Агротехнологічні та організаційні засади фрункціонування підприємств закритого ґрунту : монографрія. Київ : Центр учбової літератури, 2016. 384 с.

10. Про державну підтримку сільського господарства України : Закон України від 24.06.2004 № 1877IV. URL: https://zakon.rada.gov.ua/laws/card/1877-15 (дата звернення: 12.05.2021).

11. Проект Закону України про основні засади державної аграрної політики та державної політики сільського розвитку від 04.10.2018 № 9162. URL: http://w1.c1.rada.gov.ua/pls/zweb2/ webproc4_1?pf3511=64742 (дата звернення: 12.05.2021).

12. Прохватілова Б.О. Роль соціально-психологічних методів в управлінні персоналом підприємства. Сучасні виклики у розвитку менеджменту і маркетингу аграрного сектору економіки України : матеріали 72-ї наук.-практ. студентської конфр. (м. Київ, 29 жовтня 2018 р. Київ, 2018. URL: https://nubip.edu. ua/sites/default/files/zbirnik_tez.pdf (дата звернення: 12.05.2021).

13. Урба C.I. Узгодження параметрів розвитку аграрного сектора економіки та зміцнення продовольчої безпеки України. Молодий вчений. 2019. № 7 (1). С. 146-152.

14. Чайка В.О. Стратегія розвитку овочівництва захищеного ґрунту в умовах асоціації з ЄС. Економічний вісник університету. 2015. Вип. 27 (1). C. 72-77.

15. Чайка В.О. Забезпечення конкурентоспроможності овочів закритого ґрунту в умовах виходу на європейський ринок. Стан та перспективи розвитку бухгалтерського обліку і контролю на підприємствах АПК. Київ : КНЕУ, 2014. Вип. 2. С. 238-246. 